

\section{VOL. XVI.-1901.}

THE

\section{JOURNAL OF LARYNGOLOGY,}

\section{RHINOLOGY, AND OTOLOGY;}

AN ANALYTICAL RECORD OF CURRENT LITERATURE

RELATING TO

\section{THE THROAT, NOSE, AND EAR.}

PUBLISHED MONTHLY.

Z2onชon:

REBMAN, LIMITED, 129, Shaftesbury Avenue, Cambridge Circus, W.C.

BNTERED AT STATIONERS' HALL. 8 


\section{THE JOURNAL OF LARYNGOLOGY RHINOLOGY, AND OTOLOGY.}

Founded in 1887 by MORELL MACKENZIE and NORRIS WOLFENDEN.

EDITORS :

JOHN MACINTYRE, M.B., M.Ch., F.R.S.E. DUNDAS GRANT, M.A., M.D., F.R.C.S. Eng. ARTHUR SANDFORD, M.D., M.Ch.R.U.I.

R. LAKE, F.R.C.S.

W. MILligaN, M.D., Sub-Editor.

W. JOBSON HORNE, M.A., M.D.; B.C. Camb., M.R.C.P. Lond., Managing Sub-Editor.

WITH THE CO-OPERATION OF

Drs. Baron (Bristol), Price-Brown (Toronto), Cartaz (Paris),

Bryson Delavan (New York), Dodo (Chicago), Donelan (London),

Grazzi (Florence), Gurk (Amsterdam), Hicguet (Brussels),

Middlemass Hunt (Licerpool), Hutohison (Brighton), Joal (Paris),

Kally (Glasgow), Lacoarret (Toulouse), Lichtwitz (Bordeaux),

Lieven (Aix-la-Chapelle), John N. Mackenzin (Baltimore), Prof. Masser (Naples),

Meyjes (Amsterlam), Mrles (New York), Holger Mygind (Copenhagen),

Porter (St. Louis), Guild (Dundee), Sachs (Hamburg),

StGeorge Rhid (London), Sajous (Philadelphia), Seninziak (Warsaw),

Sota (Seville), StClair Thomson (London), WagGetr (London),

Woods (Dublin), and Ziem (Dantzic). 


\section{LIST ()F PLATES.}

Plates I., II.-To illustrate Dr. Hunter Tod's paper on Atresia Auris Congenita - - - To face 106; 108

To illustrate Dr. Lodge's case of Sarcoma of the Naso-

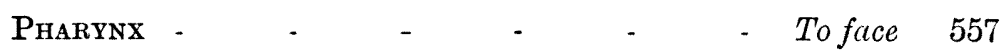

Plates I., II.-To illustrate Dr. Jobson Honne's paper on the Larynx-a Site of Infection in Certain Diseases of the Lymphatic Glands - - To face 686,688 


\section{CONTENTS.}

Obituary Notice-

PAGE

Rufus Pratt Lincoln, M.D.

\section{Special Articles-}

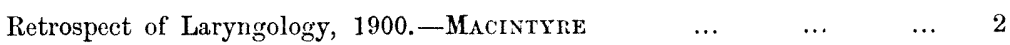

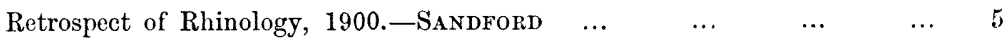

Retrospect of Otology, 1900.-Dundas Grant and Atwood Thorne $\quad \ldots \quad 7$

Angeioma of the Larynx in a Boy aged Six Years, removed under Chloroform $\begin{array}{llllllll}\text { by an Endolaryngeal Method.-Brady } & \ldots & \ldots & \ldots & \ldots & 14\end{array}$

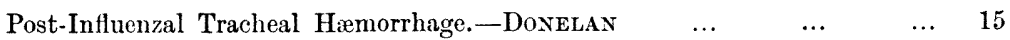

Mouth-Breathing, and its Relation to Diseases of the Throat, Ear, Nose and $\begin{array}{llllllll}\text { Accessory Cavities.-Maxo Collier } & \ldots & \ldots & \ldots & \ldots & 21\end{array}$

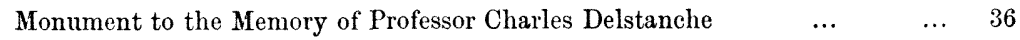

\section{Society's Proceedings-}

$\begin{array}{llllllll}\text { The Laryygological Societr of Loxdon } & \ldots & \ldots & \ldots & & . & 36\end{array}$

\section{Abstracts-}

$\begin{array}{llllllllll}\text { Nose, Erc. } & \ldots & \ldots & \ldots & \ldots & \ldots & \ldots & \ldots & 49\end{array}$

$\begin{array}{lllllllllll}\text { LARYXX } & \ldots & \ldots & \ldots & \ldots & \ldots & \ldots & \ldots & \ldots & 50\end{array}$

$\begin{array}{lllllllllll}\operatorname{EAR} & \ldots & \ldots & \ldots & \ldots & \ldots & \ldots & \ldots & \ldots & 51\end{array}$

$\begin{array}{llllllllllll}\text { PhARYNX } & \ldots & \ldots & \ldots & \ldots & \ldots & \ldots & \ldots & \ldots & 55\end{array}$

\section{Reviews-}

Beitrage zur Frage der Volksheilstätten. - H. WeICkER $\quad \ldots \quad \ldots \quad \ldots \quad 55$

$\begin{array}{llllllll}\text { The British Sanatoria Annual } & \ldots & \ldots & \ldots & \ldots & \ldots & 56\end{array}$

\section{GUIDE TO ADVERTISEMENTS.}

\begin{tabular}{|c|c|c|c|c|c|}
\hline Bullock \& Co. & $\ldots$ & $\ldots$ & $\ldots$ & $\ldots$ & $\ldots$ \\
\hline Burroughs Wellcome \& C & & $\ldots$ & $\ldots$ & $\ldots$ & $\ldots$ \\
\hline Central London Throat, & Nose & Ear & ital & $\ldots$ & $\ldots$ \\
\hline Davies \& Long $\quad \ldots$ & $\ldots$ & $\cdots$ & $\cdots$ & $\cdots$ & $\cdots$ \\
\hline Down Bros. & $\ldots$ & $\cdots$ & $\cdots$ & $\ldots$ & $\ldots$ \\
\hline Ingram \& Royle ... & $\ldots$ & $\ldots$ & $\cdots$ & $\ldots$ & iv, $v$ \\
\hline Lambert Pharmacal Co. & $\ldots$ & $\ldots$ & $\ldots$ & $\ldots$ & $\ldots$ \\
\hline Maw, Son \& Thompson & $\ldots$ & $\ldots$ & $\ldots$ & $\cdots$ & $\ldots$ \\
\hline Maycr \& Meltzer ... & $\ldots$ & $\ldots$ & $\ldots$ & $\ldots$ & $\ldots \quad \mathrm{ix}, \mathrm{xi}$ \\
\hline Metropolitan Ear, Nose a & nd $T$ & Ho & & $\ldots$ & $\ldots$ \\
\hline Nelson Dale \& Co., Ltd. & $\ldots$ & $\ldots$ & $\ldots$ & $\ldots$ & $\ldots$ \\
\hline Rebman, Limited & $\ldots$ & $\ldots$ & $\cdots$ & $\ldots$ & ... iii, $x, x i$ \\
\hline Tibble's Vi-Cocoa & $\ldots$ & $\cdots$ & $\cdots$ & $\ldots$ & ${ }^{\cdots} 1-2^{\text {viii }}$ \\
\hline
\end{tabular}




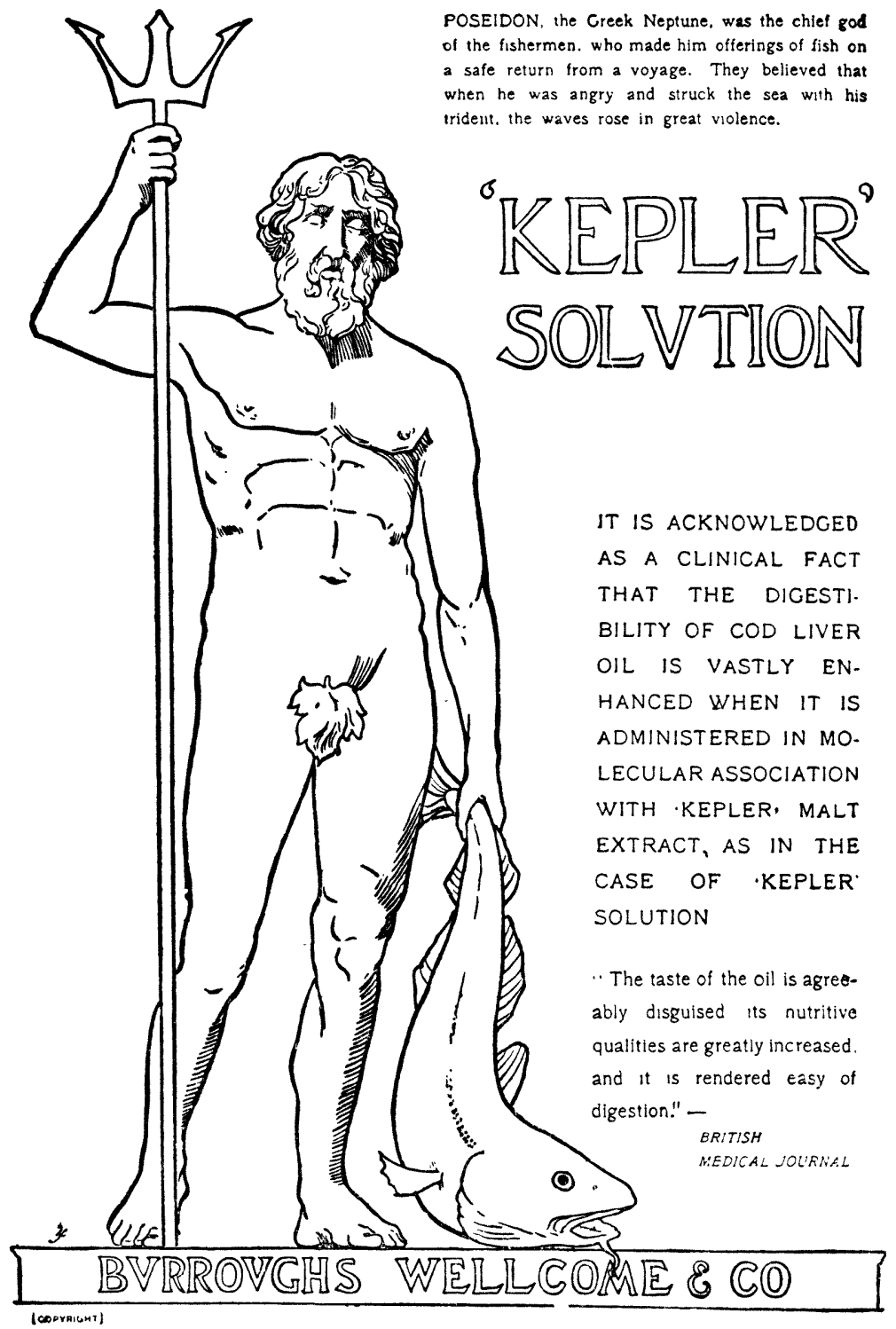

POSEIDON, the Greek Neptune. was the chief god of the fishermen. who made him offerings of fish on a safe return from a voyage. They believed that when he was angry and struck the sea with his trident, the waves rose in great violence.

IS IS ACKNOWLEDGED AS A CLINICAL FACT THAT THE DIGESTI. BILITY OF COD LIVER OIL IS VASTLY ENHANCED WHEN IT IS ACED WHEN IT IS AECULAR ASSOCIATION WITH 'KEPLER, MALT EXTRACT, AS IN THE CASE OF 'KEPLER SOLUTION

-The taste of the oil is agreeably disguised its nutritive qualities are greatly increased. and it is rendered easy of digestion." -

BRITISH

MEDICAL JOLRLF. 